\title{
High-quality Class Management in the Development of Higher Vocational Education
}

\author{
Jiaxin $\mathrm{Hu}^{1}$ \\ ${ }^{1}$ College of Computer Science and Electronic Engineering, Hunan University, Changsha, Hunan \\ *Corresponding author. Email: alice19971020@126.com
}

\begin{abstract}
According to the national strategy and the needs of today's regional industrial development, promoting vocational education has become the top priority, and its development has broad prospects and great potential. President $\mathrm{Xi}$ Jinping has highlighted the importance of accelerating the development of a modern vocational education system and cultivating more high-caliber technical professionals as China moves toward socialist modernization. How to change the class management mode and improve the class quality in higher vocational colleges, and how to cultivate highquality professional and technical talents with all-round development of morality and technology, it is important to improve the overall quality of educators, improve teaching methods, refine the positioning of vocational education, and explore the development of vocational education system with Chinese characteristics. This paper will analyze the advanced experience of western vocational education, take the freshman class of a vocational school in Hunan Province as an example, fundamentally analyze the factors that affect the class management, and put forward solutions.
\end{abstract}

Keywords: class management, class teaching, students' behaviors analysis, curriculum construction, teachers' team construction

\section{RESEARCH BACKGROUND AND SIGNIFICANCE}

We should analyze the advanced concepts and practice methods of international occupation education, and extract the essence and keep up with the national policies. The action plan for improving the quality of Vocational Education (2020-2023) points out that teachers, teaching materials and curriculum construction are the key elements related to the improvement of the quality of education. We should systematically promote the "three education" reform of Vocational Education: first, improve the "double teacher" quality of teachers; second, strengthen the construction of vocational education teaching materials; third, improve the teaching quality of vocational education specialty and curriculum. In view of the high-quality class management, the background of vocational education, the construction of teachers and the management of students have become the important decisive factors affecting the classroom management.

\section{THE CONCEPT OF VOCATIONAL EDUCATION IN WESTERN COUNTRIES}

The higher vocational education in western developed countries is quite different from that in China due to the differences in historical and cultural background and economy. Western countries generally attach importance to the practical training and quality education of students, from the stage training in school to lifelong training. And for the teachers' growth plan, Germany, the United States and other countries established the basic paradigm of teacher standards on professional standards and qualification certification, which has the characteristics of formulating standards according to law, reasonable structure and keeping pace with the times, and has been widely praised and recognized [1].

\subsection{Higher Vocational Education in America}

Vocational and technical education in the United States covers a wide range of disciplines [2]. 
In terms of curriculum construction, its educational philosophy emphasizes that it should adapt to the economic and social development and ensure that the teaching content is closely related to the position of the educated [3].

In terms of the construction of teaching staff, the United States pays more attention to employment training during work. This training is based on the needs of in-service teachers and the needs of social development, which aims to improve and enhance teachers' professionalism and professional skills. Teachers' in-service training should be carried out in stages according to the contents of the courses and practical requirements, so as to obtain the corresponding teacher qualification certificate. This similar vocational skill certificate is more targeted than the universal university teacher qualification certificate. From the perspective of practice, its advantage is that it can enable teachers to reflect on teaching problems in time in the process of teaching activities, which is conducive to the improvement of teachers' professional teaching knowledge [4].

\subsection{Higher Vocational Education in Japan}

Japan's higher vocational education system consists of short-term universities, specialized schools, higher specialized schools and other diversified educational institutions.

In terms of curriculum construction, it emphasizes the cultivation of students' practical ability, attaches importance to the cultivation of students' personality and cultural education, and adapts to the trend of social development.

In terms of the construction of teaching staff, Japan has established a solid quality assurance mechanism for teachers in higher vocational education from three aspects: the standard of teachers in higher vocational education, the source of teachers and the development of teachers on the job [5]. The policy ensures the high quality and stable development of teachers by means of high salary and college entrance examination standards, so as to ensure the quality of teaching.

\subsection{Higher Vocational Education in Germany}

"Dual system" is the most unique and characteristic content in German vocational education, and it is also the key to the success of its vocational education. Teachers in schools and teachers in enterprises are the two teaching subjects to carry out vocational education in Theory and Practice for students.

In terms of curriculum construction, German schools do not set up moral courses, but rely on the "hidden education" of various disciplines to cultivate students' most basic moral quality and behavior standards, and cultivate students' self-restraint, mutual cooperation and meticulous spirit.

In terms of the construction of the teaching staff, Germany attaches great importance to the training before and during the work period; Teachers on the job should teach according to the school teaching content and the actual needs of enterprise production.

\section{ANALYSIS OF THE STATUS OF CLASS IN HIGHER VOCATIONAL EDUCATION}

Since 2018, the generation after 00s has gradually become the main body of students in higher vocational colleges. In view of these groups, we should analyze their classroom situation, analyze their ideological and behavioral characteristics from the root, and carry out effective teaching reform, so as to ensure the teaching quality of higher vocational education.

\subsection{Characteristics and Behaviors of Students in Class}

This paper takes the freshmen of Hunan vocational college of electronic and technology as an example.

Table1. Characteristics and behaviors of students in Class

\begin{tabular}{|l|l|}
\hline \multicolumn{1}{|c|}{$\begin{array}{c}\text { Students' } \\
\text { characteristics }\end{array}$} & \multicolumn{1}{c|}{ Corresponding behaviors } \\
\hline $\begin{array}{l}\text { Self-denial and lack of } \\
\text { achievement }\end{array}$ & Lower learning enthusiasm \\
\hline $\begin{array}{l}\text { No immediate and } \\
\text { long-term goals }\end{array}$ & No short-term learning objectives \\
\hline $\begin{array}{l}\text { Focus on new media } \\
\text { and games }\end{array}$ & Play mobile phones in class \\
\hline $\begin{array}{l}\text { Poor self-control and } \\
\text { inattention }\end{array}$ & Distracted in class \\
\hline
\end{tabular}

\subsection{Detailed Analysis of Students' Characteristics}

\subsubsection{Self-denial and Lack of Achievement}

Higher vocational college students have a sense of self negation. They think that their education level is low and they can't find a high matching job in the society. This leads to the decrease of their learning enthusiasm and motivation. In the class, the interest in the course is reduced, and the sense of achievement can not be obtained from the professional practice.

\subsubsection{No Immediate and Long-term Goals}

After the questionnaire survey, $77.5 \%$ of the students have no long-term goals, only $22.5 \%$ of the 
students have clear goals. Whether they understand the significance of learning and whether we have a clear direction for future employment directly determines the efficiency of class learning.

\subsubsection{Focus on New Media and Games}

Things in the new era continue to develop, especially in the case of the Internet. Students will focus on the Internet games, which leads to their use of mobile phones in the classroom, thus affecting their personal learning efficiency and class atmosphere.

\subsubsection{Poor self-control and inattention}

Students' attention can not focus on the content of the course, which will lead to classroom disorder, and teachers can not normally teach according to the teaching plan.

\section{ANAL YSIS OF THE REASONS FOR THE POOR MANAGEMENT OF VOCATIONAL EDUCATION CLASS IN CHINA}

In 2019, the two sessions of the National People's Congress of the people's Republic of China decided to expand the enrollment of higher vocational education. The scale of it is expanding rapidly, which has the same status as general education, but has distinct professional characteristics. But at present, it is still in the stage of development as a whole, which is a weak link in the higher education system.

Class is the most important part of vocational education. Teachers, students and schools all play important roles. If each role is independent and uncoordinated, the effect of class management will be worse. Here are the reasons for poor class management.

\subsection{Imperfect Curriculum System}

Because of the practical characteristics of higher vocational education, its teaching materials should contain new technology and practical operation guidance. But some vocational colleges have not been able to apply the latest textbooks to the classroom, they still use old textbooks, and the theory is not updated. At the same time, teachers do not update the teaching content in time, and still use the original teaching plan. As a result, students are unable to follow up social technology in time and lose their confidence in learning. Finally, students do not listen to the class, which is difficult to manage.

\subsection{Weak Students' Self-control}

Most of the students' self-control is poor, and the learning atmosphere of the whole class needs to be improved.
For example, taking freshmen majoring in software technology as an example, $35 \%$ of the students think that they should not play mobile phones in class, and $65 \%$ of the students think that other students play mobile phones is not related to them, which leads to more and more students begin to imitate. When half of the students in the class begin to turn their attention to mobile phones, the management of the class will be difficult to maintain.

\subsection{Poor Management Ability of Teachers}

In terms of class teaching, some teachers only focus on whether the course content has been taught, but not on whether the students understand it and whether it can be used in practice. This leads to students' Weariness in the process of learning, and produces a vicious circle. In terms of class discipline: teachers only focus on whether the teaching plan has been completed, rather than control the classroom discipline. Students' behaviors of sleeping, playing games and speaking often appear in some classes, but teachers do not stop them effectively, and sometimes even conflict with students. Students are no longer convinced of the teachers, and the class is difficult to manage.

\subsection{Imperfect School Facilities}

Some vocational schools have no library and study room, and the teaching environment is poor, which makes it impossible to form a good learning atmosphere among students. Due to the particularity of vocational education, students should focus on practice. Taking software technology as an example, students need a good computer environment, and computer hardware and software play an important role. If the facilities are not perfect, students will not be able to complete the practical tasks in time.

\section{HIGH QUALITY CLASS MANAGEMENT STRATEGY}

\subsection{Construction of High Quality Curriculum System}

All departments and teaching and research departments should update the teaching plan in time and introduce the teaching materials that are really suitable for students in higher vocational colleges. The selection of teaching materials can be carried out by teachers and enterprises.

In the aspect of class quality management, the scoring system should be adopted, and senior students and educational staff should be randomly selected to form a scoring group. Educational administrators should summarize and publicize the final scores to solve the problems of corresponding teachers in time. 


\subsection{Cultivate Students' Initiative in Autonomous Learning}

The main body of the classroom is teachers and students. For different students, teachers should teach them in accordance with their aptitude.

For students with active thinking, group discussion and independent exploration mode can be adopted to let students show their achievements, so as to enhance students' self-confidence and promote the overall learning atmosphere of the class. For introverted students, homework and personal defense can be used to test their learning results. For students with poor learning autonomy, game cases can be integrated in the teaching process to arouse students' attention and ensure normal classroom teaching.

\subsection{Introduce High Quality Professionals and Stabilize the Structure of Teachers}

The construction of teaching staff is the main body to help vocational college students improve their professional quality. The ability and quality of the teaching staff are directly related to the improvement of students' professional quality [6].

Higher vocational colleges need to improve the organization and management mechanism of teachers' team construction. Based on the national policy, the construction method of teachers' team with one school and one characteristic should be put forward, so as to improve the management level of teachers' team and promote the long-term development of teachers' team in Higher Vocational colleges.

As for the reserve of talents, higher vocational colleges can introduce double first-class college students as reserve talents. During the holidays, teachers should be trained (including moral quality training, professional knowledge training and teaching mode training). The mechanism of helping vocational schools can be implemented, attracting excellent master and doctoral students to enter the higher vocational class, spreading campus culture and teaching professional knowledge. At the same time, excellent enterprise talents can be introduced to drive students' enthusiasm for practice. The above-mentioned teachers' team construction needs incentive system, for example, to mobilize the enthusiasm and initiative of teachers through awards.

\section{CONCLUSION}

Based on the background of million enrollment expansion, there are still some problems in the class management of Higher Vocational Education in China. It is necessary to conduct research in different types of higher vocational colleges. The fundamental factors affecting class management are worth exploring, and the problems should be solved according to the root causes.

\section{REFERENCES}

[1] Zhai Zhihua.On the Cultivation of "DoubleQualified Teachers" in China from the Standards of Vocational Education Teachers in Developed Countries-Taking Germany, the United States, the United Kingdom and Australia as Example[J]. Journal of Wuhan Engineering Institute. 2020,32(04):78-82.

[2] Christopher Zirkle, Pan Bai-xiang. An Introduction of the Multi-tiered CTE/VTE System in the United States-From High School to Four-year Colleges (in Chinese)[J].Journal of Huzhou Vocational and Technological College. 2020,18(03).

[3] Yao Wenjie, He bin. Characteristics, experience and Enlightenment of undergraduate vocational education in developed countries -- Based on the analysis of Germany, the United States and Japan (in Chinese)[J]. Education and Occupation. 2020 (17): $81-88$

[4] Zuo Qian. Characteristics, experience and reference of teacher training in American Vocational Education (in Chinese) [J]. Vocational \& Technical Education Forum, 2019 (08): 171-176.

[5] Chen Jun, Wang Liyan, Liu Xudong. On high quality promotion mechanism of Japanese Higher Vocational Education and its highlights (in Chinese) [J]. Vocational and Technical Education, 2016,37 (20): 70-74.

[6] Cui Yun. Vocational craftsman education of computer major (in Chinese) [J]. Electronic Technology, 2021,50 (02): 150-151. 